\title{
Measurement of fats, oil and grease by spectro-photometry and its application on different sites at São Paulo State, Brazil
}

\author{
D. M. Bonotto, L. Caprioglio, M. Torres, H. K. Itoman \\ \& R. Dalmora \\ Departamento de Petrologia e Metalogenia, \\ Instituto de Geociências e Ciências Exatas-UNESP, Rio Claro, Brazil
}

\begin{abstract}
This investigation was carried out within the Paraná sedimentary basin, Brazil, involved the sampling of effluents and groundwater from monitoring stations situated at different sites at São Paulo State, and was realized with the purpose of evaluating the presence of fats, oil and grease (FOG) in different matrices. Several tests were realized with very distinct materials (cooking oil, butter, margarine, pig fat, vacuum pump oil) in order to properly calibrate the spectrophotometric system. Each matrix was dissolved with 1,1,1-trichloroethane and from the stock solutions it was prepared working standards from different dilutions. The data obtained were plotted on absorbance vs. concentration graph that yielded a successful calibration curve when a mineral oil for vacuum pump was utilized in the experiments at a wavelength corresponding to $410 \mathrm{~nm}$. The results obtained for the analyzed samples were compared with the limiting value established by the São Paulo State legislation on the prevention and pollution control of the environment that was established in $8^{\text {th }}$ September 1976 by Rule No. 8468 .
\end{abstract}

Keywords: fats, oil, grease, spectrophotometry, vinasse, dairy effluents, groundwater, São Paulo State.

\section{Introduction}

The fats, oil and grease (FOG) found in food ingredients such as meat, cooking oil, shortening, butter, margarine, baked goods, sauces and dairy products is a 
major concern for sewers occurring in several municipalities worldwide. When not disposed properly, FOG builds up in the sewer system constricting flow, which can cause sewer back-ups into homes and overflow discharges onto streets [1].

It is also well known that as little as one quart of oil can contaminate 100,000 gallons of drinking water and similarly each time it rains, hydrocarbon petroleum material is being washed off of concrete surfaces as "run-off" finding its way into the natural environment [2]. Thus, there is a general consensus that oil, grease, gasoline and other hydrocarbon petroleum based chemicals are harmful to the environment and need to be effectively removed. As a consequence, some manufacturers of commercial liquid cleaning chemicals, solvents, and degreasers have been developing products designed to emulsify and solubilize oil, grease, gasoline and along with very large quantities of "rinsing water" and power equipment provided a solution for cleaning concrete, but this process also creates contaminated toxic waste-water that finds its way into soil, storm drains, sewer systems, underground watersheds, and into much larger bodies of water where organic life is being negatively impacted [2].

Therefore, for many years, environmentalists, humanitarians, government agencies, politicians, educators, and others have expressed the concern for protecting the environment and our natural resources against FOG releases [2]. One very important aspect for this consist on obtaining reliable analytical testing methods to be used by industrial and municipal facilities to analyze FOG and non-polar materials in aqueous matrices, such as those proposed by the U.S. Environmental Protection Agency (EPA) [3].

In Brazil, waste disposal areas related to dairy products may also be a source of contaminants to the hydrologic environment. This is the case for some sites located in municipalities occurring in the interior of São Paulo State, which is the most industrialized Brazilian state.

This paper describes a methodological approach developed for charactering FOG in water and effluents through spectrophotometry at $410 \mathrm{~nm}$. The technique was properly calibrated by adequate manufactured standards and successfully applied to different effluents stored in reservoirs/decantation ponds, as well to underground water sampled in several monitoring wells. All results obtained in this investigation are here reported.

\section{General features of the spectrophotometric method}

Despite several analytical techniques have been developed for measuring FOG in different environmental matrices, the spectrophotometry has been adopted in this study due to practical reasons, such as wide applicability and facility of the calibration procedures.

A Hach Model DR 2000 spectrophotometer was employed to measure the amount of light that a sample absorbs. The instrument operates by passing a beam of light through a sample and measuring the intensity of light reaching a detector. The beam of light consists of a stream of photons, so that when a photon encounters an analyte molecule, there is a chance the analyte will absorb 
the photon. This absorption reduces the number of photons in the beam of light, thereby reducing the intensity of the light beam.

For making spectrophotometric measurements, the intensity of light $\left(I_{0}\right)$ passing through a blank is initially measured. The blank is a solution that is identical to the sample solution except that the blank does not contain the solute that absorbs light. This measurement is necessary, because the cell itself scatters some of the light. Then, the intensity of light $(I)$ passing through the sample solution is measured and the experimental data is used to calculate two quantities: the transmittance $(T)$ and the absorbance $(A)$. These parameters are evaluated by the following equations: $T=I \div I_{0}$ and $A=-\log _{10} T$ [4].

Among the major factors that affect the amount of light a sample absorbs are [4]: a) the cell path length- is the length of sample that the light passes through. The cell path length is represented by the symbol $l$ and is typically measured in centimeters; b) the analyte concentration- the analyte is the substance that absorbs the light, i.e. it is the substance that is being analyzed in the experiment. The concentration is represented by the symbol $c$ and is typically measured in mole. $\mathrm{L}^{-1}$. These two parameters are often combined to yield a general equation called Beer's Law, expressed by $A=\varepsilon . l . c$, where $\varepsilon$ is the molar absorptivity (extinction coefficient) [4]. The molar absorptivity varies with the wavelength of light used in the measurement. The absorption spectrum is sometimes displayed in the form $\varepsilon$ vs. $\lambda$ rather than $A$ vs. $\lambda$ [4].

Therefore, the extent to which a sample absorbs light depends strongly upon the wavelength of light. For this reason, spectrophotometry is performed using monochromatic light, i.e. light in which all photons have the same wavelength. In analyzing a new sample, it is a common practice to determine the sample's absorbance spectrum which shows how the absorbance of light depends upon the wavelength of the light. The spectrum itself is a plot of absorbance vs. wavelength and is characterized by the wavelength $\left(\lambda_{\max }\right)$ at which the absorbance is the greatest. The value of $\lambda_{\max }$ is important as it is characteristic of each compound and provides information on the electronic structure of the analyte. In order to obtain the highest sensitivity and to minimize deviations from Beer's Law, analytical measurements are often made using light with a wavelength of $\lambda_{\max }$ [4].

To establish the calibration curves by the spectrophotometric method, the readings are often plotted on semilogarithmic paper as $\%$ transmittance vs. concentration (or absorbance vs. concentration on linear-linear paper). As an example, a sample calibration for iron concentrations of 0 to $2 \mathrm{mg} / \mathrm{L}$ has been described in the literature [5]. Figure 1 shows the $\%$ transmittance values plotted on the logarithmic (vertical) scale and the concentration values on the linear (horizontal) scale. In the example, iron standard solutions of $0.2,0.4,0.8,1.2,1.6$ and $2 \mathrm{mg} / \mathrm{L}$ were measured on a Spectronic 20 Spectrophotometer at $500 \mathrm{~nm}$ [5].

Having in mind the described aspects related to the spectrophotometric measurements, the Hach Model DR 2000 spectrophotometer was calibrated for performing FOG concentration readings. The experimental steps were held at LABIDRO (Laboratory of Isotopes and Hydrochemistry) of Petrology Department from Geosciences and Exacts Sciences Institute that belongs to 
UNESP, situated at Rio Claro city. The calibration curve reported by [5] was prepared using California crude oil by diluting $0.10 \mathrm{~g}$ of the oil to $100 \mathrm{~mL}$ with 1,1,1-trichloroethane, and the readings were performed at $450 \mathrm{~nm}$. However, the most favorable wavelength setting should be determined for each particular oil, for instance California crude oil has a higher percentage of tars and less aromatics than most Texas crude oils [5]. Therefore, several tests were realized at LABIDRO with various matrices (cooking oil, butter, margarine, pig fat, vacuum pump oil, etc.) in order to properly calibrate the spectrometric system. Each matrix was dissolved with 1,1,1-trichloroethane and from the stock solutions it was prepared working standards from different dilutions. The data obtained were plotted on absorbance vs. concentration graphs, but, unfortunately in most of the cases it was not possible obtain reliable calibration curves due to the lack of color contrast, as shown for pig fat in Fig. 2. The unique successful calibration curve was found when the mineral oil for Edwards E2M8 vacuum pump was utilized in the experiments at a wavelength corresponding to $410 \mathrm{~nm}$, as illustrated in Fig. 2.

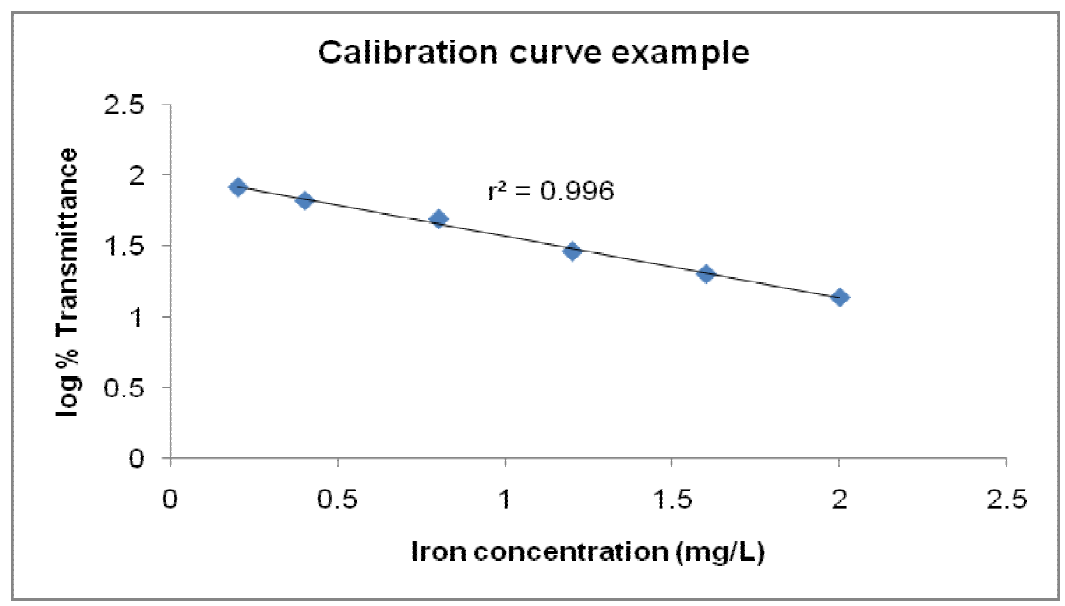

Figure 1: The calibration curve of the Spectronic 20 Spectrophotometer for performing iron concentration readings at $500 \mathrm{~nm}$ [5].

\section{Some FOG sources investigated at São Paulo State}

São Paulo is the most populous Brazilian state, comprising $\sim 40$ million inhabitants distributed over 645 municipalities. It has the highest number of industries and economic production, reaching 31\% of the Brazilian GDP-gross domestic product. Despite the vigorous industrial production that includes high technology goods, the state also is well developed in agriculture and cattle breeding [6]. This advanced stage of agricultural and industrial growth causes to São Paulo State a great diversity of problems related to the interaction between the society and the environment. 


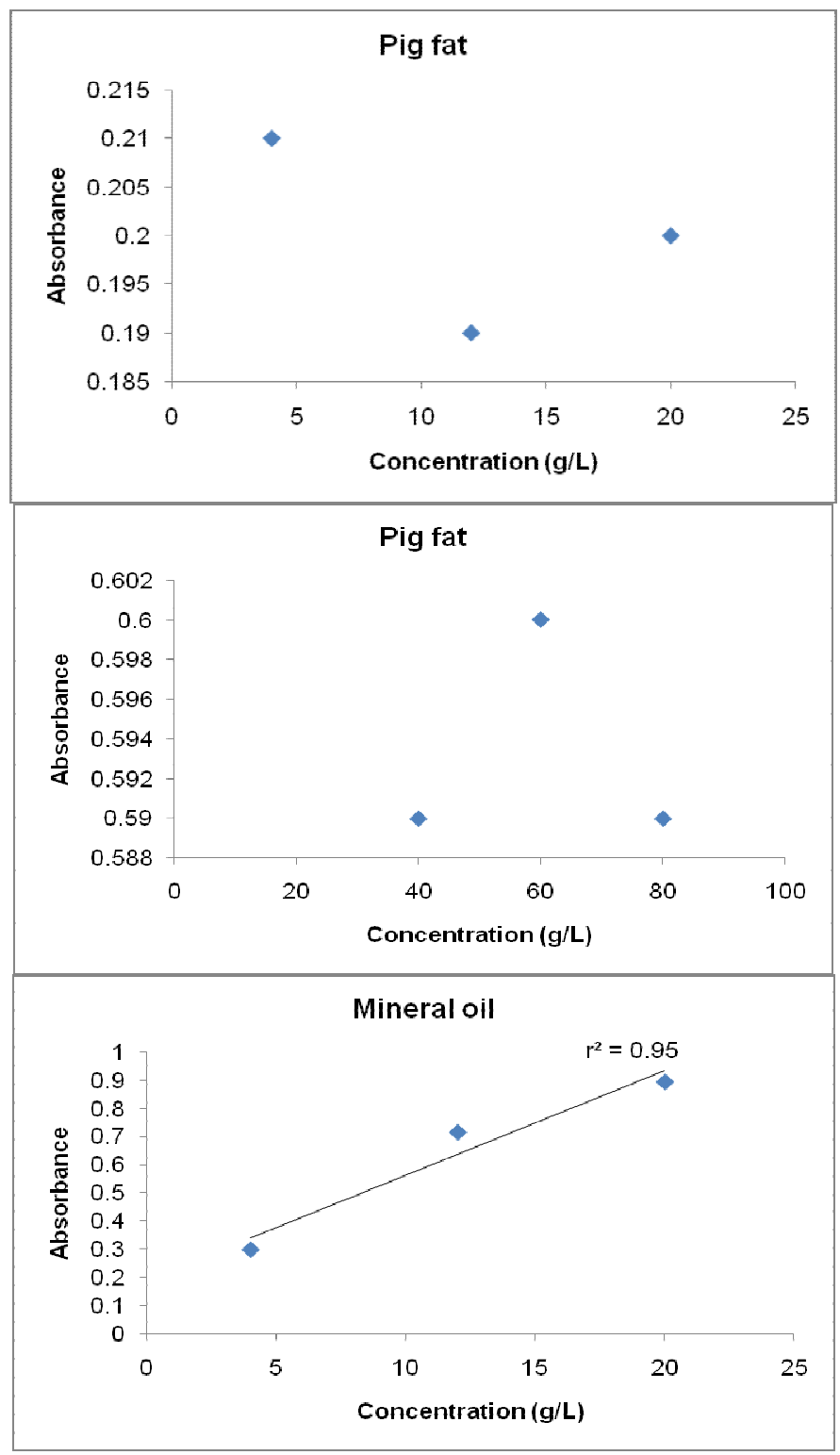

Figure 2: The calibration curve of the Hach Model DR 2000 Spectrophotometer for performing FOG concentration readings at $410 \mathrm{~nm}$.

Considering the central, southeastern and southern Brazilian regions, the number of units responsible by the production and processing of sugarcane are: 49- São Paulo State; 23- Paraná State; 8- Mato Grosso do Sul State; 5- Minas 
Gerais State; 5-Mato Grosso State; 4- Goiás State; 2- Espírito Santo State; 1- Rio de Janeiro State [7]. During 2007, the sugarcane production at these states reached 375 million tons, whose processing yielded 17.2 billion liters of alcohol and 23.7 million tons of sugar [8]. Thus, São Paulo State was responsible for almost $50 \%$ of this production.

The disposal of vinasse, the major effluent from the ethanol industry, represents a major environmental problem at São Paulo State. Vinasse is a final byproduct of the sugar industry. Sugar beet is processed to produce crystalline sugar, pulp and molasses. The latter are further processed by fermentation to alcohol. After the removal of the alcohol by distillation the remaining material is vinasse. Molasses is a thick syrup by-product from the processing of the sugarcane or sugar beet into sugar [9]. To make molasses, which is pure sugar cane juice, the sugar cane plant is harvested and stripped of its leaves. Its juice is extracted from the canes, usually by crushing or mashing. The juice is boiled to concentrate and promote the crystallization of the sugar. Cane molasses is a common ingredient in baking, often used in baked goods such as gingerbread cookies.

Vinasse is a black liquid consisting of a mixture of water and organic and inorganic compounds that remain after different steps involving the sugar cane production and processing. It is produced at a rate 10 to 15 times greater than the ethanol itself, i.e. in terms of volume, approximately $13 \mathrm{~L}$ of vinasse are produced by each $\mathrm{L}$ of alcohol obtained from cane must $[10,11]$. Considering the high amount of alcohol produced by São Paulo State during 2007, it may be estimated the generation of about 100 billion liters of vinasse that represents an enormous volume to be released into the environment.

Vinasse compounds may also be a FOG source and are considered hazardous substances because they have a very high BOD-Biological Oxygen Demand (30$40,000 \mathrm{mg} / \mathrm{L}$ ) and $\mathrm{pH}$ between 4 and 5 [10]. Thus, vinasse is a residue highly corrosive and research has demonstrated that its disposal in river basins alone isn't a convenient disposal solution. Due to its high BOD, this material can cause damage to aquatic life, especially when dumped in large volumes [12, 13].

Another important aspect is that among the factors affecting sugarcane productivity is fertilization. However, mineral fertilizers have significantly increased their prices. As a result, it has become necessary to seek alternatives that would supply the soil with more economic nutrients. Because vinasse has high levels of potassium, calcium and organic matter in its chemical composition as well as moderate amounts of nitrogen and phosphorus $[10,11]$ it has represented an alternative to supply such nutrients in crop production, as have been reported by various research works documenting an increase on the sugarcane productivity, mainly in Brazil $[14,15]$. However, the problem occurs when some soils don't respond positively to the application of this acid material. The disposal problem is aggravated by an economic drawback, because water must be evaporated for easy transportation at low costs.

The cattle breeding at São Paulo State also is an important economic activity, as the number reaches 12.6 million, the $5^{\text {th }}$ in Brazil. However, in terms of exportation, $70 \%$ of the Brazilian meat leaves São Paulo State through Santos harbor. The state contributes with about 2 billion liters of milk per year that 
represents $\sim 10 \%$ of the Brazilian milk production, but despite this São Paulo State is the main center consuming dairy products in the country $[16,17]$. Thus, during their production, some FOG may be discharged into the environment.

The number of gas stations suppliers at São Paulo State corresponds to 7500 that is significant if compared with 28500 existing in Brazil. They must provide fuel to about 15 million vehicles in São Paulo State, but such number is increasing, for instance, raised 26\% from 2002 to 2006 [18]. Therefore, FOG releases associated to gas stations suppliers also constitute an important environmental question to be solved by São Paulo State authorities.

\section{The spectrophotometric method applied to selected sites at São Paulo State}

For the purpose of this investigation, the method described in item 2 was applied to areas situated at São Paulo State that are potentially affected by FOG releases into the environment. They are located at northwestern part of the state in the following municipalities: Santo Antônio do Aracanguá, José Bonifácio, Penápolis and Araçatuba (Fig. 3). In terms of geology, the region is situated at the Paraná sedimentary basin. The sedimentary sequence is almost undisturbed, with gentle dips towards the center of the basin, and covers since the SilurianDevonian up to the Cretaceous periods. The major rock types [19] include sandstones, conglomerates, diamictites, siltstones, shales, mudstones, limestones, basalts and diabases that belong to Tubarão Group (Itararé Subgroup and Tatuí Formation), Passa Dois Group (Irati and Corumbataí Formations), São Bento

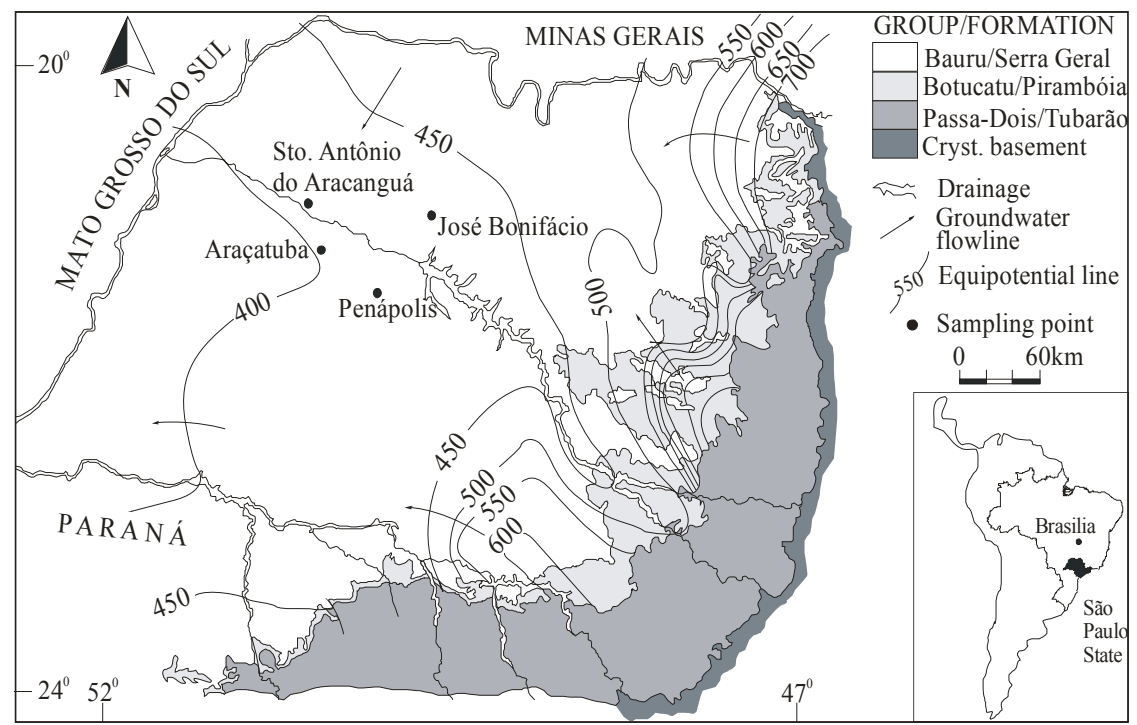

Figure 3: A simplified geological map of São Paulo State and the general groundwater flow in Guarani aquifer according to [21]. 
Group (Pirambóia, Botucatu, and Serra Geral Formations), Bauru Group and different types of Cenozoic covers (Fig. 3).

Multiaquifer systems mainly comprising sandstones and basalts plus sediments from Passa Dois Group behaving as aquitards have been proposed to represent the hydrostratigraphy of the Paraná basin [20]. Groundwater occurs within the interflow zones and along cooling joints in basalts and diabases from Serra Geral Formation. The sandstones of Cretaceous age (Bauru Group) are moderately cemented and exhibit adequate properties to storage water. The Paleozoic sediments (Devonian-Permian age) also provide water that is relatively mineralized in the central parts of the basin and contains $\mathrm{H}_{2} \mathrm{~S}$ in some wells. The Guarani aquifer corresponds to sediments (Triassic-Jurassic age) consisting of silty and shaly sandstones of fluvial-lacustrine origin (Pirambóia Formation) and variegated quartzitic sandstones accumulated by eolian processes under desert conditions (Botucatu Formation). It has continental dimensions [20], extends over some $950,000 \mathrm{~km}^{2}$ within the Paraná sedimentary basin, has an average thickness of 300-400 m, overlies formations ranging from the igneous basement to Paleozoic sediments of the Passa Dois and Tubarão Groups, and is covered by a thick (up to $1,500 \mathrm{~m}$ ) basaltic package of Serra Geral Formation and Cretaceous sediments of the Bauru Group (Fig. 3).

Table 1: $\quad$ The municipalities of São Paulo State and matrices studied in this investigation. The data for the municipalities are from [22].

\begin{tabular}{|c|c|c|c|c|c|}
\hline Parameter & Unit & $\begin{array}{l}\text { Araçatuba } \\
\text { city }\end{array}$ & $\begin{array}{l}\text { Penápolis } \\
\text { city }\end{array}$ & $\begin{array}{c}\text { José } \\
\text { Bonifácio } \\
\text { city }\end{array}$ & $\begin{array}{l}\text { Santo Antônio do } \\
\text { Aracanguá } \\
\text { city }\end{array}$ \\
\hline Population & Inhabitants & 178,839 & 56,681 & 30,639 & 7,034 \\
\hline Area & $\mathrm{km}^{2}$ & 1,167 & 709 & 859 & 1,306 \\
\hline Bovines & Number & 80,170 & 22,117 & 97,258 & 62,614 \\
\hline Milk & $10^{3} \mathrm{~L}$ & 6,042 & 3,825 & 9,955 & 5,754 \\
\hline Sugarcane & Tons & $1,342,783$ & $1,519,475$ & 186,921 & $1,808,813$ \\
\hline Vehicles & Automobiles & 44,259 & 12,848 & 6,795 & 767 \\
\hline $\begin{array}{c}\text { Matrix } \\
\text { analyzed }\end{array}$ & - & $\begin{array}{l}\text { Ground- } \\
\text { water }\end{array}$ & $\begin{array}{l}\text { Groundwater + } \\
\text { Dairy effluents }\end{array}$ & $\begin{array}{l}\text { Ground- } \\
\text { water }\end{array}$ & Vinasse \\
\hline Site & - & $\begin{array}{l}\text { Monitoring } \\
\text { wells }\end{array}$ & $\begin{array}{c}\text { Monitoring } \\
\text { wells }+ \\
\text { Reservoirs }\end{array}$ & $\begin{array}{l}\text { Monitoring } \\
\text { wells }\end{array}$ & $\begin{array}{l}\text { Decantation } \\
\text { ponds }\end{array}$ \\
\hline Owner & - & $\begin{array}{l}\text { Cacique } \\
\text { gas station }\end{array}$ & $\begin{array}{c}\text { CIESA + } \\
\text { Laticínios } \\
\text { Campesina }\end{array}$ & $\begin{array}{c}\text { Borracharia } \\
\text { Paulista }\end{array}$ & Aralco \\
\hline
\end{tabular}

The sampling for FOG analysis was performed for vinasse and dairy effluents stored at reservoirs/decantation ponds, and also for groundwater collected at monitoring wells installed around a gas station supplier and in fields irrigated with vinasse for sugarcane crop. The samples were subjected to the same treatment realized during the experimental steps held for the standards prepared 
for plotting the calibration curve of the spectrophotometric method. Some general characteristics of the municipalities investigated and the types of matrices analyzed for FOG are given in Table 1.

\section{Results and discussion}

The results for FOG analysis are reported in Table 2. The highest FOG concentration values were found for the samples of dairy effluents collected in reservoirs at Penápolis city. The samples of vinasse also exhibited high FOG concentration values, but lower than the dairy effluents.

Table 2: $\quad$ Results obtained for FOG analysis by spectrophotometry in different matrices studied in this work.

\begin{tabular}{|c|c|c|c|}
\hline \multicolumn{2}{|c|}{ José Bonifácio city } & \multicolumn{2}{|c|}{ Araçatuba city } \\
\hline Well No. & $\begin{array}{c}\text { Concentration } \\
(\mathrm{g} / \mathrm{L})\end{array}$ & Well No. & Concentration $(\mathrm{g} / \mathrm{L})$ \\
\hline 1 & $<0.01$ & 1 & $<0.01$ \\
\hline 2 & $<0.01$ & 2 & $<0.01$ \\
\hline 3 & $<0.01$ & 3 & $<0.01$ \\
\hline 4 & $<0.01$ & 4 & 1.26 \\
\hline 5 & $<0.01$ & 5 & 0.13 \\
\hline 6 & $<0.01$ & 6 & 0.11 \\
\hline \multicolumn{2}{|c|}{ Penápolis city } & 7 & 0.18 \\
\hline Well No. & $\begin{array}{c}\text { Concentration } \\
(\mathrm{g} / \mathrm{L})\end{array}$ & 8 & $<0.01$ \\
\hline 1 & 3.1 & \multicolumn{2}{|c|}{ Santo Antônio do Aracanguá city } \\
\hline 2 & $<0.01$ & Decantation & $\begin{array}{c}\text { Concentration } \\
(\mathrm{g} / \mathrm{L})\end{array}$ \\
\hline 3 & $<0.01$ & Pond No. & \\
\hline 4 & 0.05 & 1 & 4.0 \\
\hline 5 & $<0.01$ & 2 & 1.6 \\
\hline 6 & $<0.01$ & & \\
\hline Reservoir & Concentration & & \\
\hline No. & $(\mathrm{g} / \mathrm{L})$ & & \\
\hline 1 & 304 & & \\
\hline 2 & 256 & & \\
\hline
\end{tabular}

The presence of FOG as a potential pollutant of groundwater resources at the sites studied was checked on comparing the results obtained with the maximum FOG value allowed during the release of effluents to surface waters and groundwater. The guidance value adopted as reference is provided by the São Paulo State legislation on the prevention and pollution control of the environment that was established in $8^{\text {th }}$ September 1976 by Rule No. 8468. In terms of FOG concentration, the limiting value corresponds to $100 \mathrm{mg} / \mathrm{L}(0.1$ 
$\mathrm{g} / \mathrm{L}$ ), that was only exceeded in Araçatuba city (monitoring wells Nos. 4 and 7) and Penápolis city (monitoring well No. 1).

The results obtained indicate that the anthropogenic activities taking place at the gas station in Araçatuba city and at the fields irrigated with vinasse for sugarcane crop in Penápolis city are already contaminating the underground resources. In the case of Penápolis city, the value found in groundwater $(3 \mathrm{~g} / \mathrm{L})$ is approximately the same of that for vinasse itself $(4 \mathrm{~g} / \mathrm{L})$, indicating its high capacity of infiltration and ability to reach the groundwater table.

The high FOG concentration in dairy effluents suggests that much attention has to be given to its potential use for the irrigation of agricultural fields. The samples studied were well stored in reservoirs isolated from direct contact with soils, as the behavior of these effluents has not been properly evaluated yet for checking its migration capacity into the ground.

As a conclusion, it may pointed out that the calibration curve plotted for the spectrophotometric method utilized in this investigation provided the successful analysis of very different matrices. Despite the technique may not be sensible enough to yield low FOG concentration values, it is greatly useful for environmental studies focusing areas characterized by the disposal of hazardous wastes.

\section{Acknowledgement}

CNPq (National Council for Scientific and Technologic Development) in Brazil is thanked for financial support of this investigation.

\section{References}

[1] Preventing fats, oil and grease discharges into sewers; New York city Department of Environmental Protection, Online. www.nyc.gov/html/dep/ html/harbor_water/grease.shtml

[2] Bio bugs eats oil \& grease; Clean America Supply, LLC, Online. www.cleanam.com/site/viewCategory.asp?idCategory $=81$

[3] Fact Sheet: Method 1664, Oil and Grease, Revision A; U.S. Environmental Protection Agency, Online. www.epa.gov/waterscience/methods/method/ oil/ 1664fs.html

[4] Chemistry experiments and exercises; David N. Blauch, Online. www.chm.davidson.edu/ChemistryApplets/index.html

[5] HACH, Water Analysis Handbook, 2nd edn., Hach Company: Loveland, 1992.

[6] Uma potência chamada São Paulo; Portal do Governo do Estado de São Paulo, Online. www.saopaulo.sp.gov.br/saopaulo

[7] Santos Associados, Região centro-sul tem 97 usinas em operação. Clipping Açúcar \& Álcool, 22, 2007.

[8] Cana, açúcar e álcool: tendência de estabilidade; John Deere, Online. www.deere.com/pt_BR/ag/veja_mais/info_mercado/sugar_cane.html 
[9] Tejada, M. \& Gonzalez, J.L., Effects of two beet vinasse forms on soil physical properties and soil loss. Catena, 68, pp. 41-50, 2006.

[10] Cortez, L.A.B. \& Brossard Pérez, L.E., Experiences on vinasse disposal. Brazilian Journal of Chemical Engineering, 14 (1), pp. 1-14, 1997.

[11] Gómez, J. \& Rodríguez, O., Effects of vinasse on sugarcane (Saccharum officinarum) productivity. Rev. Fac. Agron., 17, pp. 318-326, 2000.

[12] COPERSUCAR, Aplicação de vinhaça à soqueira da cana de açúcar em tres anos consecutivos. Boletim Técnico Copersucar, 12, pp. 2-5, 1980.

[13] COPERSUCAR, Efeitos da aplicação da vinhaça como fertilizante em cana de açúcar. Boletim Técnico Copersucar, 7, pp. 9-14, 1986.

[14] García, A., Efecto de la concentración de electrolitos en el agua de riego, sobre la recuperación de suelos sódicos. Uso de vinazas. Suelos Ecuatoriales, 24, pp. 80-83, 1994.

[15] Glória, N.A. da, Utilização Agrícola da Vinhaça. Brasil Açucareiro, 86, pp. 11-17, 1975.

[16] Câmara setorial de leite e derivados apresenta radiografia da cadeia paulista; Secretaria de Agricultura e Abastecimento, Online. www.agricultura.sp.gov.br/ noticias2.asp?buscar=leite e derivados\&id= 1711

[17] Secretário de Agricultura participa da Conferência Anual da OIE; Secretaria de Agricultura e Abastecimento, Online.

www.agricultura.sp.gov.br/noticias2 .asp? buscar=rebanhopaulista\&id=2161

[18] Frota paulista cresce quatro vezes em relação à população; Luís Perez, Online. www2.uol.com.br/interpressmotor/noticias/item16664.shl

[19] Almeida, F.F.M. \& Melo, M.S., A bacia do Paraná e o vulcanismo Mesozóico. Mapa geológico do estado de São Paulo, ed. IPT (Instituto de Pesquisas Tecnológicas do Estado de São Paulo), Promocet: São Paulo, v. 1, pp. 46-81, 1981.

[20] Araújo, L.M., Franca, A.B. \& Potter, P.E., Hydrogeology of the Mercosul aquifer system in the Paraná and Chaco-Parana Basins, South America, and comparison with the Navajo-Nugget aquifer system, USA. Hydrogeology Journal, 7, pp. 317-336, 1999.

[21] Silva, R.B.G., Estudo hidroquímico e isotópico das águas subterrâneas do aqüífero Botucatu no Estado de São Paulo, Ph.D. Thesis, USP-São Paulo University: São Paulo, 1983.

[22] Cidades; IBGE, Online. www.ibge.gov.br/cidadesat/default.php 